\title{
Assessment of Heavy Metal Contamination in Roadside Soils Along the Shenyang-Dalian Highway in Liaoning Province, China
}

\author{
Zhang Hui ${ }^{1-3 *}$, Wu Caiqiu ${ }^{4}$, Gong Jiping', Yuan Xuyin ${ }^{5}$, Wang Qiao ${ }^{3,7}$, \\ Pei Wenming ${ }^{1}$, Long Tao ${ }^{1}$, Qiu Jie ${ }^{1}$, Zhang Hanpei ${ }^{6}$ \\ ${ }^{1}$ Nanjing Institute of Environmental Sciences, Ministry of Environmental Protection of China, \\ Nanjing 210042, China \\ ${ }^{2}$ Collaborative Innovation Center of Atmospheric Environment and Equipment Technology, \\ College of Geography and Remote, Nanjing University of Information Science and Technology, \\ Nanjing 210044, China \\ ${ }^{3}$ School of Geographical Sciences, Nanjing Normal University, Nanjing 210023, China \\ ${ }^{4}$ Shanghai Water Supply Administration, Shanghai, 200081, China \\ ${ }^{5}$ College of Environment, Hohai University, Nanjing 210098, China \\ ${ }^{6}$ The University of Hawaii, Honolulu, 96815, USA \\ ${ }^{7}$ Satellite Environment Center, Ministry of Environmental Protection of China, \\ Beijing 100029, China
}

Received: 21 November 2016

Accepted: 9 February 2017

\begin{abstract}
Heavy metal contaminations were assessed through a detailed soil survey in roadside soils along the Shenyang-Dalian Highway of Liaoning Province, China. $\mathrm{Pb}, \mathrm{Cu}, \mathrm{Cd}, \mathrm{Ni}$, and $\mathrm{Zn}$ were analyzed using atomic absorption spectrophotometry. The average concentrations of $\mathrm{Pb}, \mathrm{Cu}, \mathrm{Cd}, \mathrm{Ni}$, and $\mathrm{Zn}$ in roadside soils were $43.8,26.5,0.119,32.1$, and $71.3 \mathrm{mg} / \mathrm{kg}$, respectively, and all concentrations exceeded the background values. Different heavy metal distribution patterns were found under different land use types. In farmland, a peak metal concentration occurred $25 \mathrm{~m}$ from the roadside soil, while in the forest and orchard soil all heavy metals decreased with distance from the roadside, which conformed to the exponential model. Heavy metal concentrations were markedly higher than those measured in 1999 and 2007, except for Cd. Concentrations in soils along the Shenyang-Dalian Highway were medium or low in comparison with roadside soils in other cities around the world. Overall, this assessment illustrates that heavy metal pollution in these soils is generally low, and we recommend that more attention should be given to $\mathrm{Pb}$ contamination in roadside soils along the Shenyang-Dalian Highway.
\end{abstract}

Keywords: heavy metal contamination, Nemerow pollution index, Shenyang-Dalian Highway, roadside soils

*e-mail: zhanghui@nies.org or zhanghuinies@163.com 


\section{Introduction}

Rapid economic development has led to rapid expansion of the highway transportation industry in China, which has resulted in increases in the emissions of such contaminants as heavy metals [1]. Roadside soils tend to accumulate pollutants directly emitted from vehicle exhaust, and soils can easily come into contact with pedestrians and inhabitants near the roads, either via inhalation of suspended particles or by direct contact [2]. Exposure to inhalable emissions from roadways has been implicated as a threat to human health and is associated with an increased risk of respiratory illness [3-5]. Research has shown that adverse health effects associated with proximity to roads are strongly related to tailpipe emissions [6-7]. The most common heavy metals introduced to environments in the proximity of traffic activity and road construction are lead $(\mathrm{Pb})$, copper $(\mathrm{Cu})$, cadmium $(\mathrm{Cd})$, zinc $(\mathrm{Zn})$, chromium $(\mathrm{Cr})$, and nickel (Ni) [8-11]. The use of leaded petroleum is the primary source of $\mathrm{Pb}$ emissions (before unleaded gasoline entered circulation in China in 2000) [12]. To increase the octane rating of fuel, tetraethyl $\mathrm{Pb}$ had been added to gasoline as an anti-knock agent since 1921. Following combustion of tetraethyl $\mathrm{Pb}, \mathrm{Pb}$ is converted to $\mathrm{PbO}$ and $\mathrm{PbO}_{2}$ before being released to the atmosphere [13]. Although most countries have banned leaded gasoline since the 1990s [14], roadside soil remains a reservoir of $\mathrm{Pb}$ contamination [15]. Tire and break wear, oil spills, and erosion of road surfaces and building materials contribute to $\mathrm{Zn}, \mathrm{Cu}, \mathrm{Cr}$, $\mathrm{Cd}$, and Ni pollution [16-18]. Heavy metals can remain in soil for extended periods because they degrade slowly, posing a severe risk to ecosystems and threatening human health through exposure pathways such as inhalation of dust, dermal contact, and ingestion of crops grown in the soil.

A number of studies have examined the spatial distribution of heavy metals and factors influencing their levels in roadside dust, soils, and crops [19-22]. Kristensson et al. [23] found that gaseous emissions are higher in Sweden than in the USA and Switzerland, foremost due to the lower-fraction catalytic converters in Sweden. Along the outer-ring highway of Shanghai of China, concentrations of $\mathrm{Pb}$ and $\mathrm{Cd}$ were higher in roadside dust, and $\mathrm{Cu}$ and $\mathrm{Zn}$ in dust are mainly from heavy traffic on the highway [1]. In soil near the street in Baotou, concentrations of $\mathrm{Ba}, \mathrm{Co}, \mathrm{Cr}$, and $\mathrm{Pb}$ were significantly higher than acceptable values for human health. High levels of these elements may be attributed to the influence of transportation activities [24]. Although traffic emissions contribute to increased heavy metal concentrations in soil, heavy metals concentrations in roadside crops depend not just on their concentrations in soil, but on soil characteristics, soil environment, and crop species [25]. Metals are commonly emitted from vehicle exhaust as dust, which readily accumulate in soils; it is therefore important to assess the distribution and concentration of heavy metals in roadside soils.
Farmland is the primary land use type along both sides of the highways in most parts of China. It is important to understand the characteristics and extent of heavy metal pollution in soil to ensure the safety of agricultural production and to provide a scientific basis for agricultural planning and construction. The objective of this research is to assess heavy metal $(\mathrm{Pb}, \mathrm{Zn}, \mathrm{Cd}, \mathrm{Ni}$, and $\mathrm{Cu})$ pollution of roadside soils along the Shenyang-Dalian Highway. The specific goals are to 1) assess the spatial distribution of heavy metal pollution in the study area, 2) examine the correlation between heavy metals and distance from the road in different land use types, 3) compare the heavy metals concentrations between different years and land use areas, and 4) identify the heavy metal contamination levels.

\section{Materials and Methods}

\section{Study Area}

The study was conducted along the oldest and busiest highway, the Shenyang-Dalian Highway, in northeastern China, which is also one of the most critical areas for the production of rice and wheat in China. The highway, which is $375 \mathrm{~km}$ long, was the first expressway open to traffic in mainland China, and also the first eight-lane expressway. When it was completed in 1990, it had four lanes with full intercommunication and relates to a full intercommunication overpass. After widening was completed in 2004, it became an eight-lane highway with a maximum speed of $120 \mathrm{~km} / \mathrm{h}$. The road passes through five major cities in the province of Liaoning: Shenyang, Liaoyang, Anshan, Yingkou, and Dalian. There is an abundant amount of farmland and orchard land on both sides of the highway. The annual prevailing wind direction in Liaoning is southwest.

\section{Sample Collection}

Twenty sample sites (S1-S20) along the highway were selected (Fig. 1) and collected in July 2013. Soil samples were taken $5,25,50,100,200$, and $300 \mathrm{~m}$ from the road edge on both sides at each site (Fig. 1). Because of the terrain constraints, partial sampling distance intervals were not complete and GPS was used to record the coordinates of the sample locations. At each sampling location five surface soils $(0-5 \mathrm{~cm}$, approximately $1,000 \mathrm{~g}$ each) at all 20 sample sites were taken respectively and mixed. The soil samples were stored in polyethylene bags for transportation and storage. As shown in Fig. 1, sites S1 and S2 were located in Shenyang; S3, S4, and S5 were located in Liaoyang; S6, S7, and S8 were located in Anshan; S9-15 were located in Yingkou; and S16-20 were located in Dalian. 


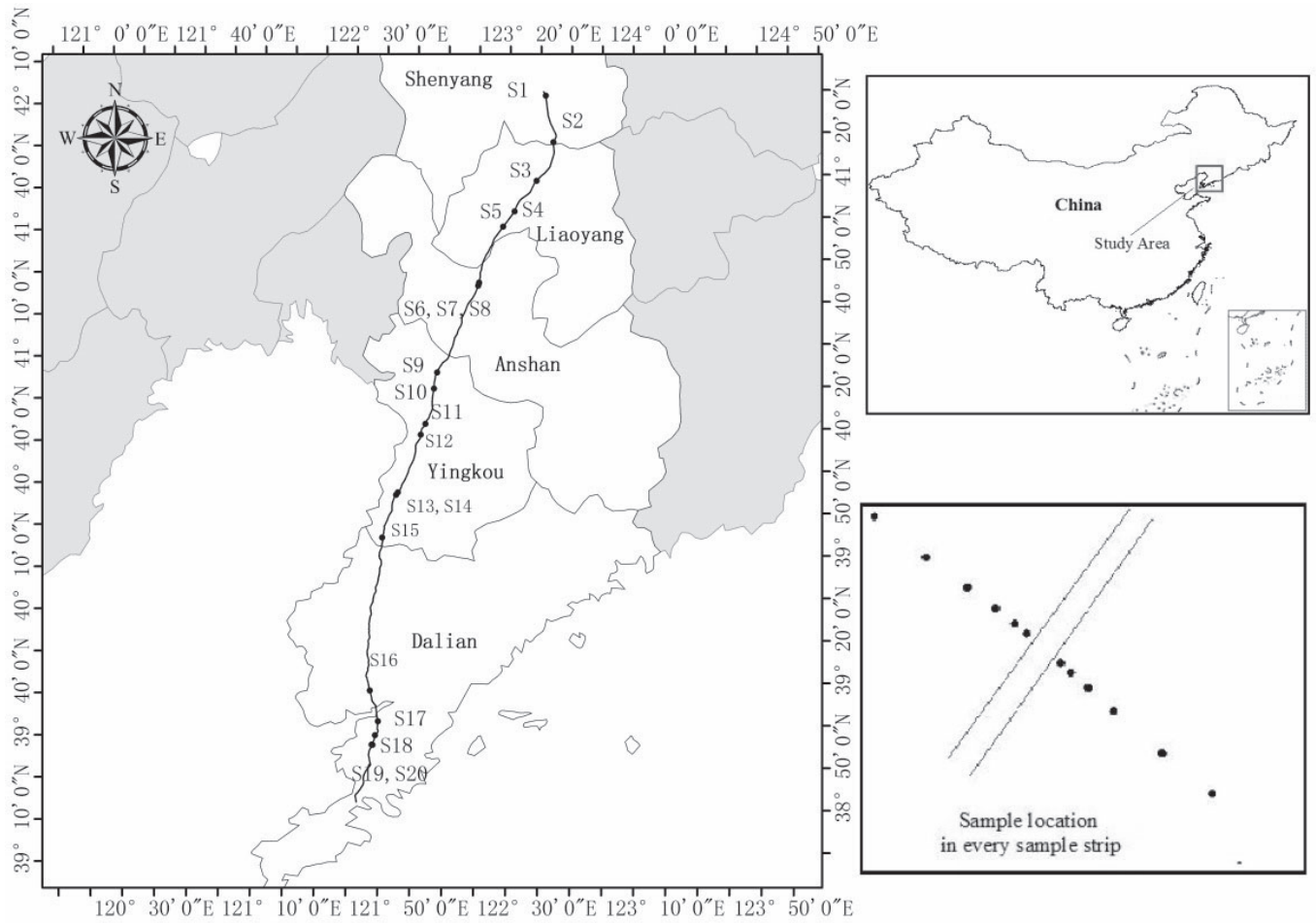

Fig 1. Location of the sampling sites along the Shenyang-Dalian Highway.

\section{Sample Preparation and Analysis}

All samples were air dried and passed through a 2-mm polyethylene sieve to remove rocks, leaves, and other debris, then ground with an agate mortar and sieved through a $0.15-\mathrm{mm}$ polyethylene sieve. All handling procedures were carried out without contacting any metals to avoid potential cross-contamination of the samples.

Approximately $1.0 \mathrm{~g}$ of each soil sample was digested primarily in a mixture solution of $\mathrm{HNO}_{3}-\mathrm{HCl}$ (1:3), then added $\mathrm{HClO}_{4}$ for further digestion. The total concentrations of $\mathrm{Pb}, \mathrm{Cu}, \mathrm{Ni}$, and $\mathrm{Zn}$ in the digested samples were determined using flame atomic absorption spectrophotometry, and $\mathrm{Cd}$ was determined using graphite furnace atomic absorption spectrometry. Standard reference materials GSS-6 (geochemical standard soil) was used for quality assurance and quality control. The recovery rate of the metals ranged from $90 \%$ to $110 \%$.

\section{Data Analysis}

Descriptive analysis and correlation analysis were performed with SPSS v.19.0 (SPSS Inc., Chicago, USA). Graphics were produced with Origin 8.0.

\section{Pollution Index}

The level of heavy metal pollution was assessed using an advanced pollution index (Pi) for each metal, and the Nemerow pollution index (PI) of the five metals [45]. The Pi can be calculated from the following formulas:

$$
\begin{aligned}
& P_{i}=C_{i} / X_{a} \quad\left(C_{i} \leq X_{a}\right) \\
& P_{i}=1+\left(C_{i}-X_{a}\right) /\left(X_{b}-X_{a}\right) \quad\left(X_{a}<C_{i} \leq X_{b}\right) \\
& P_{i}=2+\left(C_{i}-X_{b}\right) /\left(X_{c}-X_{b}\right) \quad\left(X_{b}<C_{i} \leq X_{c}\right) \\
& P_{i}=3+\left(C_{i}-X_{c}\right) /\left(X_{c}-X_{b}\right) \quad\left(C_{i}>X_{c}\right)
\end{aligned}
$$

...where $C_{i}$ is the measured concentration of each metal, and $X_{a}, X_{b}$, and $X_{c}$ are threshold concentrations indicating no pollution, low pollution, and high pollution, respectively. According to the soil standards proposed by the Environmental Protection Administration of China [46], we assigned these values as the natural background value, the critical value indicating levels potentially harmful for humans, and the critical value indicating normal growth of plants. So the values of $X_{a}, X_{b}$, and $X_{c}$ respectively, are defined as follows [2]: 21.4, 300, and $500 \mathrm{mg} / \mathrm{kg}$ for $\mathrm{Pb} ; 19.8,100$, and $400 \mathrm{mg} / \mathrm{kg}$ for $\mathrm{Cu} ; 0.108,0.3$, and $1.0 \mathrm{mg} / \mathrm{kg}$ for $\mathrm{Cd} ; 25.6,50$, and $200 \mathrm{mg} / \mathrm{kg}$ for $\mathrm{Ni}$; and $63.5,250$, and $500 \mathrm{mg} / \mathrm{kg}$ for $\mathrm{Zn}$. The Pi can be classified into the following pollution levels: no pollution $\left(P_{i} \leq 1\right)$, low pollution $\left(1<P_{i} \leq 2\right)$, moderate pollution $\left(2<P_{i} \leq 3\right)$, and high pollution $(P>3)$. The formula to calculate PI for the five metals of each sampling point is as follows:

$$
P I=\sqrt{\frac{P_{\text {imax }}^{2}+P_{\text {iave }}^{2}}{2}}
$$

...where $P_{\text {imax }}$ is the maximum value of $P_{i}$ of all the metals and $P_{\text {iave }}$ is the mean $P_{i}$ value of the metals. The PI was classified as follows: no contamination $(\mathrm{PI} \leq 0.7)$, 
possible contamination $(0.7<\mathrm{PI} \leq 1)$, low contamination $(1<\mathrm{PI} \leq 2)$, moderate contamination $(2<\mathrm{PI} \leq 3)$, and high contamination (PI $>3)$.

\section{Results and Discussion}

\section{Heavy Metal Concentrations in Soils}

Descriptive analytical results of $\mathrm{Pb}, \mathrm{Cu}, \mathrm{Cd}, \mathrm{Ni}$, and $\mathrm{Zn}$ concentrations in roadside soil are provided in Table 1. The heavy metal concentrations ranged widely. The mean concentrations of $\mathrm{Pb}, \mathrm{Cu}, \mathrm{Cd}, \mathrm{Ni}$, and $\mathrm{Zn}$ in roadside soils along the Shenyang-Dalian Highway were 43.8, 26.5, $0.119,32.1$, and $71.3 \mathrm{mg} / \mathrm{kg}$, respectively. These values are higher than the background value for the province of Liaoning. The ratios of the average concentration to the background value for $\mathrm{Pb}, \mathrm{Cu}, \mathrm{Cd}, \mathrm{Ni}$, and $\mathrm{Zn}$ were 2.05:1, 1.34:1, 1.10:1, 1.25:1, and 1.12:1, respectively.

Among the five road segments, the concentrations of $\mathrm{Pb}$ and $\mathrm{Zn}$ were the highest along the Shenyang road segment (the traffic volume is also highest in this road segment). Lawrence et al. [26] also found that the concentration of polycyclic aromatic hydrocarbons and other organics varies significantly at the entrance and exit sites of the tunnel, with fluoranthene, pyrene, benzo[a] pyrene, chrysene, and benzothiazole having the highest incremented concentrations. The Yingkou road segment contained the highest concentrations of $\mathrm{Cu}$ and $\mathrm{Zn}$. High concentrations of $\mathrm{Cu}$ in this segment may be attributed to

Table 1. Concentrations of heavy metals in roadside surface soil along the Shenyang-Dalian Highway.

\begin{tabular}{|c|c|c|c|c|c|c|}
\hline \multirow{3}{*}{ City } & \multirow{3}{*}{ Sample strip } & \multicolumn{5}{|c|}{ Concentration (mg/kg) } \\
\hline & & $\mathrm{Pb}$ & $\mathrm{Cu}$ & $\mathrm{Cd}$ & $\mathrm{Ni}$ & $\mathrm{Zn}$ \\
\hline & & Mean \pm S.D. & Mean \pm S.D. & Mean士S.D. & Mean \pm S.D. & Mean \pm S.D. \\
\hline \multirow{2}{*}{ Shenyang } & S1 & $70.6 \pm 7.9$ & $27.0 \pm 3.8$ & $0.110 \pm 0.017$ & $21.5 \pm 2.5$ & $90.3 \pm 12.1$ \\
\hline & S2 & $35.3 \pm 4.1$ & $19.0 \pm 2.3$ & $0.087 \pm 0.010$ & $19.2 \pm 1.9$ & $103.6 \pm 39.1$ \\
\hline & Mean & $52.9 \pm 19.0$ & $23.0 \pm 5.1$ & $0.098 \pm 0.018$ & $20.4 \pm 2.4$ & $97.0 \pm 29.1$ \\
\hline \multirow{3}{*}{ Liaoyang } & S3 & $62.3 \pm 16.2$ & $25.0 \pm 1.4$ & $0.104 \pm 0.029$ & $21.5 \pm 1.9$ & $107.1 \pm 11.5$ \\
\hline & S4 & $37.4 \pm 2.2$ & $18.6 \pm 1.2$ & $0.116 \pm 0.011$ & $29.8 \pm 2.1$ & $73.7 \pm 13.0$ \\
\hline & S5 & $40.6 \pm 13.5$ & $18.3 \pm 2.0$ & $0.112 \pm 0.060$ & $21.3 \pm 4.0$ & $85.8 \pm 26.0$ \\
\hline & Mean & $48.7 \pm 17.3$ & $21.0 \pm 3.6$ & $0.107 \pm 0.026$ & $23.1 \pm 4.5$ & $91.9 \pm 22.7$ \\
\hline \multirow{3}{*}{ Anshan } & S6 & $30.5 \pm 2.8$ & $13.7 \pm 1.5$ & $0.124 \pm 0.011$ & $28.3 \pm 0.9$ & $55.5 \pm 17.6$ \\
\hline & S7 & $31.2 \pm 4.5$ & $15.3 \pm 1.6$ & $0.134 \pm 0.014$ & $32.2 \pm 3.1$ & $55.9 \pm 14.5$ \\
\hline & S8 & $38.6 \pm 3.1$ & $19.7 \pm 2.9$ & $0.162 \pm 0.019$ & $37.0 \pm 4.3$ & $67.3 \pm 21.8$ \\
\hline & Mean & $34.0 \pm 5.2$ & $16.8 \pm 3.3$ & $0.143 \pm 0.022$ & $33.3 \pm 4.7$ & $60.4 \pm 18.6$ \\
\hline \multirow{7}{*}{ Yingkou } & S9 & $40.6 \pm 3.9$ & $24.6 \pm 3.8$ & $0.153 \pm 0.021$ & $39.0 \pm 3.8$ & $72.6 \pm 18.7$ \\
\hline & S10 & $45.5 \pm 8.2$ & $29.5 \pm 7.8$ & $0.125 \pm 0.024$ & $38.0 \pm 3.6$ & $93.2 \pm 21.3$ \\
\hline & S11 & $36.0 \pm 4.7$ & $15.6 \pm 6.4$ & $0.160 \pm 0.015$ & $35.5 \pm 3.6$ & $73.6 \pm 37.0$ \\
\hline & $\mathrm{S} 12$ & $38.1 \pm 6.2$ & $17.1 \pm 5.3$ & $0.166 \pm 0.024$ & $36.4 \pm 2.9$ & $73.5 \pm 38.2$ \\
\hline & S13 & $39.4 \pm 3.2$ & $28.3 \pm 12.1$ & $0.156 \pm 0.018$ & $31.7 \pm 2.3$ & $37.2 \pm 3.5$ \\
\hline & S14 & $39.7 \pm 38.9$ & $23.1 \pm 17.2$ & $0.139 \pm 0.018$ & $33.6 \pm 3.9$ & $53.0 \pm 24.3$ \\
\hline & S15 & $71.1 \pm 22.6$ & $111.9 \pm 102.6$ & $0.038 \pm 0.015$ & $37.9 \pm 6.3$ & $114.9 \pm 78.3$ \\
\hline & Mean & $45.1 \pm 21.9$ & $37.3 \pm 53.5$ & $0.130 \pm 0.047$ & $36.1 \pm 4.5$ & $77.2 \pm 45.8$ \\
\hline \multirow{7}{*}{ Dalian } & S16 & $46.0 \pm 6.9$ & $24.4 \pm 9.5$ & $0.023 \pm 0.003$ & $39.5 \pm 6.0$ & $31.5 \pm 15.9$ \\
\hline & S17 & $42.0 \pm 10.9$ & $25.9 \pm 16.3$ & $0.166 \pm 0.019$ & $34.0 \pm 3.8$ & $71.8 \pm 42.3$ \\
\hline & S18 & $46.5 \pm 9.2$ & $22.0 \pm 7.3$ & $0.040 \pm 0.054$ & $35.8 \pm 3.8$ & $48.4 \pm 23.3$ \\
\hline & S19 & $25.3 \pm 4.0$ & $14.5 \pm 3.3$ & $0.142 \pm 0.011$ & $34.3 \pm 2.6$ & $50.2 \pm 10.2$ \\
\hline & S20 & $45.9 \pm 11.6$ & $25.4 \pm 9.3$ & $0.168 \pm 0.053$ & $34.8 \pm 4.3$ & $43.9 \pm 27.9$ \\
\hline & Mean & $41.8 \pm 12.2$ & $22.8 \pm 10.5$ & $0.108 \pm 0.073$ & $35.7 \pm 4.2$ & $50.7 \pm 28.4$ \\
\hline & Total & $43.8 \pm 17.6$ & $26.5 \pm 32.3$ & $0.119 \pm 0.052$ & $32.1 \pm 7.4$ & $71.3 \pm 37.7$ \\
\hline
\end{tabular}


Table 2. Pearson correlation coefficients of heavy metals in roadside soil samples.

\begin{tabular}{|c|c|c|c|c|c|}
\hline & $\mathrm{Pb}$ & $\mathrm{Cu}$ & $\mathrm{Cd}$ & $\mathrm{Ni}$ & $\mathrm{Zn}$ \\
\hline $\mathrm{Pb}$ & 1 & & & & \\
\hline $\mathrm{Cu}$ & $0.529^{*}$ & 1 & & & \\
\hline $\mathrm{Cd}$ & -0.094 & $-0.190^{*}$ & 1 & & \\
\hline $\mathrm{Ni}$ & 0.001 & $0.229^{*}$ & 0.107 & 1 & \\
\hline $\mathrm{Zn}$ & $0.527^{*}$ & $0.499^{*}$ & 0.113 & -0.103 & 1 \\
\hline
\end{tabular}

*The correlation is significant at the 0.01 level.
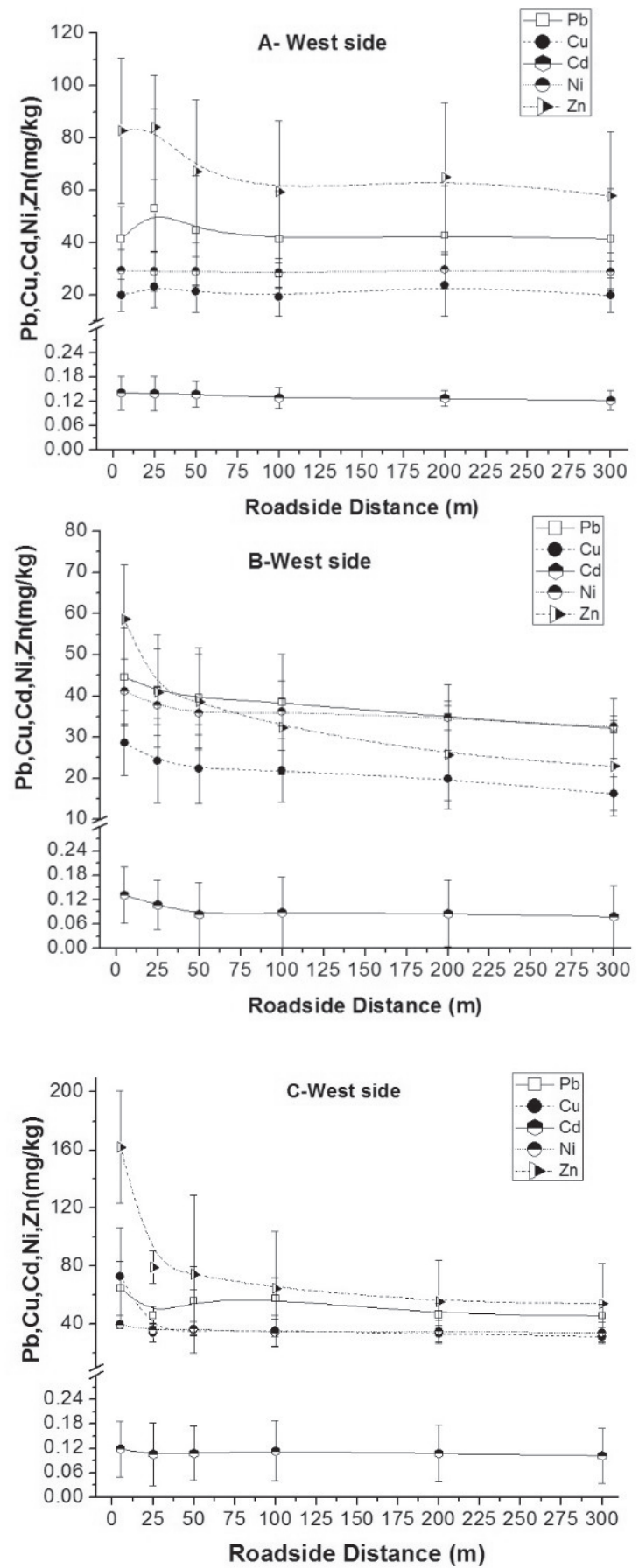

silica mining activity in Yingkou; there is a silica refinery located within 1,200 meters of S15, and omissions from ore trucks may have caused the high concentrations of $\mathrm{Cu}$. The concentration of $\mathrm{Cd}$ was highest along the Anshan road segment. This may be because most of the soil samples here were collected from fields and orchards that are influenced by agricultural activities, including irrigation and fertilization.

Pearson's correlation coefficient is frequently used to express the correlation between elements and indicate their potential sources [27]. The correlation coefficients between the heavy metals in this study are listed in
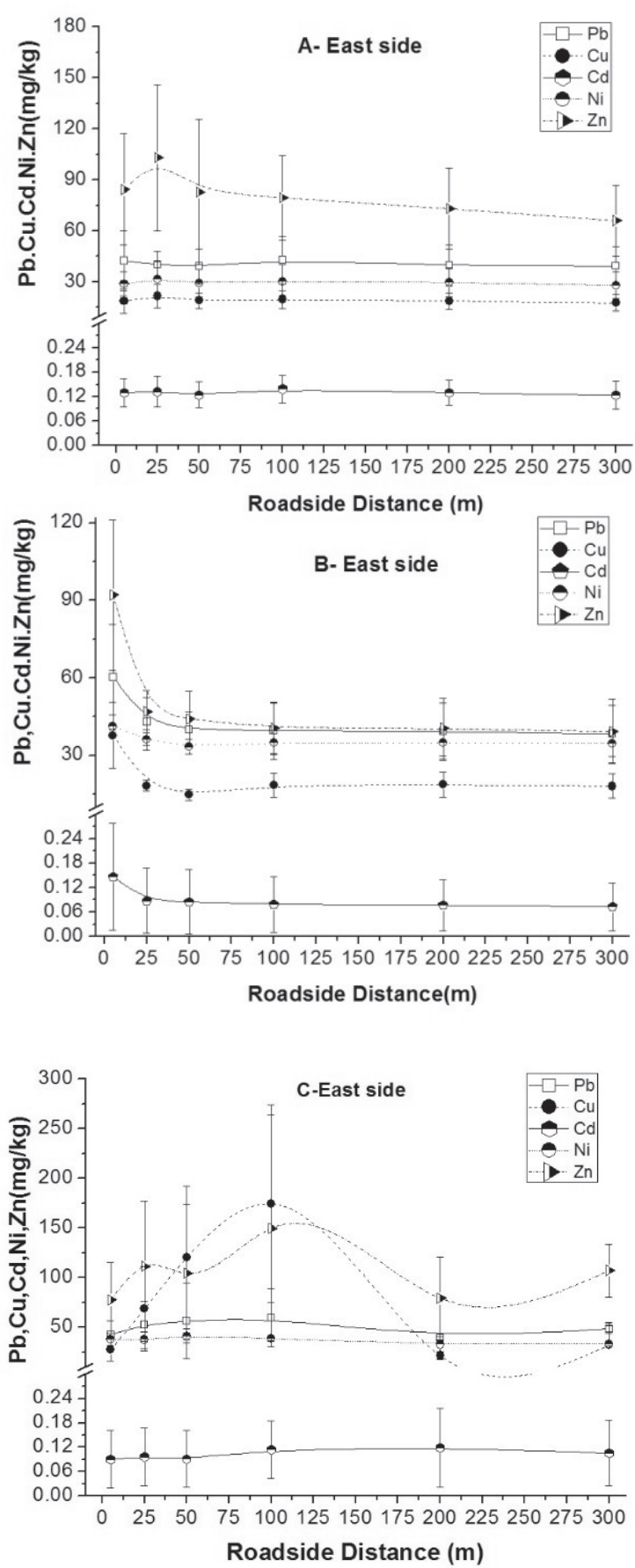

Fig. 2. Relationship between soil heavy metal concentrations and distance from the highway on both sides of the road. 
Table 3. Average concentrations of heavy metals (mg/kg) in five cities along the Shenyang-Dalian Highway in 1999, 2007 , and 2013.

\begin{tabular}{|c|c|c|c|c|c|c|c|c|c|c|c|}
\hline \multirow{2}{*}{ City } & \multicolumn{3}{|c|}{$\mathrm{Pb}$} & \multicolumn{2}{|c|}{$\mathrm{Cu}$} & \multicolumn{2}{|c|}{$\mathrm{Cd}$} & \multicolumn{2}{|c|}{$\mathrm{Ni}$} & \multicolumn{2}{|c|}{$\mathrm{Zn}$} \\
\hline & 2013 & 2007 & 1999 & 2013 & 2007 & 2013 & 2007 & 2013 & 2007 & 2013 & 2007 \\
\hline Shenyang & 52.9 & 68.9 & 25.2 & 23.0 & 26.1 & 0.098 & 0.230 & 20.4 & 24.9 & 97.0 & 36.8 \\
\hline Liaoyang & 48.7 & 26.8 & 22.6 & 21.0 & 20.1 & 0.107 & 0.080 & 23.1 & 21.0 & 91.9 & 36.6 \\
\hline Anshan & 34.0 & 33.9 & 20.41 & 16.8 & 23.4 & 0.143 & 0.150 & 33.3 & 27.0 & 60.4 & 34.1 \\
\hline Yingkou & 45.1 & 43.3 & 20.3 & 37.3 & 25.3 & 0.130 & 0.180 & 36.1 & 29.3 & 77.2 & 76.7 \\
\hline Dalian & 41.8 & 26.1 & 17.9 & 22.8 & 17.4 & 0.108 & 0.090 & 35.7 & 21.9 & 50.7 & 66.6 \\
\hline Mean value & 43.8 & 39.8 & 21.3 & 26.5 & 22.5 & 0.119 & 0.146 & 32.1 & 24.8 & 71.3 & 50.2 \\
\hline Background value & \multicolumn{3}{|c|}{21.6} & \multicolumn{2}{|c|}{21.8} & \multicolumn{2}{|c|}{0.108} & \multicolumn{2}{|c|}{25.6} & \multicolumn{2}{|c|}{63.5} \\
\hline
\end{tabular}

Note: Background values in Liaoning are referenced from soil element background values in China [46].

Table 2. We observed positive correlations between soil concentrations of $\mathrm{Pb}$ and $\mathrm{Cu}(\mathrm{r}=0.529, \mathrm{P}<0.01$, t-test $), \mathrm{Pb}$ and $\mathrm{Zn}(\mathrm{r}=0.527, \mathrm{P}<0.01$, $\mathrm{t}$-test $)$, and $\mathrm{Zn}$ and $\mathrm{Cu}(\mathrm{r}=0.499$, $\mathrm{P}<0.01$, t-test), implying that $\mathrm{Pb}, \mathrm{Cu}$, and $\mathrm{Zn}$ originated from the same source. Atmospheric deposition of these metals is associated with traffic emissions. In contrast, $\mathrm{Ni}$ was not significantly correlated with other heavy metals, and we observed low negative correlations between $\mathrm{Cd}$ and other elements, suggesting different contaminant sources. Cd was closely related with agricultural activity, and Ni mainly originated from the local parent material.

\section{Heavy Metal Concentrations at Different Distances from the Road in Different Land Use Types}

Sample strips were divided into three classes according to land use type: Class A is cultivated land, with crops such as rice and corn; Class B is orchard and forested land, with trees being the dominant vegetation type; and Class C contains orchard and forested land, as well as some industrial land on the eastern side of the sample strip. The variations in heavy metal concentrations in roadside soil at different distances from the ShenyangDalian Highway are shown in Fig. 2 and Table 4. There were not simple monotonic decreasing treads in all heavy metal concentrations with the increase of the distance from the roadside. The heavy metals in automobile exhaust diffused rely on the sorption of different particle size dusts. The adsorption effects from different heavy metals and different particle size dusts from the same heavy metal were inconsistent. Some significant differences in the distribution patterns of heavy metals between the three classes were found.

In Class $\mathrm{A}$, the element $\mathrm{Cu}$ was less than the soil background value. The ratios of the average concentration to the background value for $\mathrm{Pb}, \mathrm{Cd}, \mathrm{Ni}$, and $\mathrm{Zn}$ were 1.85:1, 1.26:1, 1.16:1, and 1.23:1, respectively. Moreover, the distribution patterns were similar on both sides of the road. On the western side, the concentrations of $\mathrm{Pb}, \mathrm{Cu}$, and $\mathrm{Zn}$ were elevated from $5 \mathrm{~m}$ to $25 \mathrm{~m}$ in this entire section; beyond $25 \mathrm{~m}$, concentrations remained at lower, steady levels. In this area, the concentrations of $\mathrm{Ni}$ and $\mathrm{Cd}$ were comparatively uniform. On the eastern side, $\mathrm{Cu}, \mathrm{Ni}$, and $\mathrm{Zn}$ increased from $5 \mathrm{~m}$ to $25 \mathrm{~m}$ in this entire section, and, as on the western side, concentrations decreased beyond $25 \mathrm{~m}$ and remained stable. Broadly speaking, in Class A there was an obvious peak in heavy metal concentrations $25 \mathrm{~m}$ from the road edge and showed the non-normal distribution. These findings were all consistent with previous studies [28-29].

Similar to Class $\mathrm{A}$, the element $\mathrm{Cu}$ was also less than the soil background value in Class $\mathrm{B}$. The ratios of the average concentration to the background value for $\mathrm{Pb}$, $\mathrm{Cd}, \mathrm{Ni}$, and $\mathrm{Zn}$ were 1.81:1, 1.14:1, 1.12:1, and 1.12:1, respectively. The distribution patterns of heavy metals were similar on both sides of the road. Concentrations of all heavy metals decreased gradually with distances in different trends. Yan et al. [30] found that heavy metal concentrations decreased exponentially with distance from the road in the Qinghai-Tibet Plateau, China. In Class B, heavy metal concentrations on the eastern side gradually decreased to a relatively low value at a distance of about $100 \mathrm{~m}$ from the road edge. The decreasing trend of concentrations of all five metals was more gradual than on the western side; however, even $300 \mathrm{~m}$ from the road edge, the concentrations continued to decrease. In Class B, the lowest metal concentration was observed $100 \mathrm{~m}$ from the road edge in the east and $300 \mathrm{~m}$ from the road in the west, where the lowest concentration was still higher than the background value; this illustrates that heavy metals were transported a greater distance in the west.

The distribution patterns differed between Class A and Class B, which may be a result of differences in land use. Heavy metals released by traffic emissions are generally released with particulate matter and do not readily settle into the roadbed because of the air turbulence caused by movement of the vehicle [31]. When particulate matter left the roadbed for some distance with the weaker space dynamic conditions of subsidence, and the condition could be availed for the deposition process of particles, thus appeared the non-normal distribution. Class A contains mainly cultivated land with rice, wheat, and corn crops. These plants are short and are less effective 
Table 4. Average concentrations of heavy metals $(\mathrm{mg} / \mathrm{kg})$ in three classes along the Shenyang-Dalian Highway.

\begin{tabular}{|c|c|c|c|c|c|}
\hline Types & $\mathrm{Pb}$ & $\mathrm{Cu}$ & $\mathrm{Cd}$ & $\mathrm{Ni}$ & $\mathrm{Zn}$ \\
\hline Class A & 40 & 20.2 & 0.136 & 29.8 & 78.2 \\
\hline Class B & 39.1 & 16.8 & 0.123 & 28.6 & 71.4 \\
\hline Class C & 42.5 & 23.7 & 0.071 & 34.9 & 38.6 \\
\hline Background value & 21.6 & 21.8 & 0.108 & 25.6 & 63.5 \\
\hline
\end{tabular}

to entrap particles, therefore particulate matter naturally was deposited with less resistance and the metals occurred at maximum concentrations $25 \mathrm{~m}$ from the road. In Class $\mathrm{B}$, the vegetation was composed mainly of trees, which, because of their height, intercept particulate matter more readily. Therefore, the maximum concentrations occurred close to the road edge, and the concentrations distribution decreased exponentially with distance from the road. $\mathrm{Cd}$ concentrations also decreased exponentially in Class B, while the concentrations of $\mathrm{Cd}$ in Class A did not vary widely with distance from the road, likely because most of the soil samples were collected from farmland and they would be exposed to the same primary source of metals: irrigation and fertilization. Concentrations of heavy metals in Class B were lower than in Class A. This also illustrated that tall trees have a greater ability to entrap heavy metals associated with particulate matter than do shorter crops.

The average concentrations of heavy metals in Class $\mathrm{C}$ were different than the other two classes. In Class $\mathrm{C}$, the elements $\mathrm{Cd}$ and $\mathrm{Zn}$ were less than the soil background value. The ratios of the average concentration to the background value for $\mathrm{Pb}, \mathrm{Cu}$, and $\mathrm{Ni}$ were 1.97:1, 1.09:1, and $1.36: 1$, respectively. Heavy metal concentrations decreased with distance on the western side of the road. Sites S10, S15, and S17 all have metal factories or mines located on the eastern side. The impact of industrial activities on soil heavy metal concentrations is complex, and in these sites there were no clear patterns in their distribution on the eastern side. This phenomenon demonstrates that the effect of industrial activities on soil metal concentrations is greater than the influence of traffic activity.

In all three classes, heavy metal concentrations on the eastern side were higher than those on the western side (Fig. 2), which is the result of the predominant wind direction in Liaoning (southwest); this is conducive to the accumulation of motor vehicle exhaust on the eastern side of the road. Heavy metals emitted from automobile exhaust occurs as very small particles, and are transported by horizontal diffusion and influenced by wind speed and direction. Thus, the emitted particles were spread over a wide area and accumulated in higher concentrations in the downwind direction. These particles accumulate on surface soil as a result of atmospheric sedimentation, compaction, and interception. Therefore, the predominant wind direction is an important factor influencing the spatial distribution pattern of heavy metals emitted from vehicle exhaust [32].

\section{Comparison of Mean Heavy Metal Concentrations in Shenyang-Dalian Highway Roadside Soils with those in Other Cities}

Heavy metal concentrations in five cities along the Shengyang-Dalian Highway were chosen to analyze the temporal variation [33-34]. As shown in Table 3, the mean $\mathrm{Pb}$ concentrations in the five cities in 1999 were below or slightly above the background values, indicating that the

Table 5. Comparison of total metal concentrations in roadside soils from selected studies.

\begin{tabular}{|c|c|c|c|c|c|c|}
\hline Location & $\mathrm{Pb}$ & $\mathrm{Cu}$ & $\mathrm{Cd}$ & $\mathrm{Ni}$ & Zn & Reference \\
\hline Galway, Ireland & 40.8 & 16.6 & -- & 22.1 & 81.8 & {$[38]$} \\
\hline Istanbul, Turkey & 191 & 68.7 & -- & -- & 255 & {$[39]$} \\
\hline Jeddah, Saudi Arabia & 47.5 & -- & -- & 46.7 & 222.2 & {$[40]$} \\
\hline Naples, Italy & 262 & 74 & -- & -- & 251 & {$[41]$} \\
\hline Kavala, Greece & 573.1 & 48.1 & 0.2 & 77.4 & 175.0 & {$[42]$} \\
\hline Ibadan, Nigeria & 307 & 31.4 & 1.36 & 38.9 & 86.1 & {$[43]$} \\
\hline Kampala, Uganda & 45.3 & -- & 1.12 & -- & 140.9 & {$[44]$} \\
\hline West Bank, Palestine & 87.4 & 60.4 & 0.27 & 18.9 & 82.2 & {$[45]$} \\
\hline Tehran-Karaj Highway, Iran & 669.30 & -- & 3.90 & 90.32 & 614.31 & {$[13]$} \\
\hline Beijing, China & 35.4 & 29.7 & 0.215 & 26.7 & 92.1 & {$[2]$} \\
\hline Liaoning, China & 43.8 & 26.5 & 0.119 & 32.1 & 71.3 & This study \\
\hline Background values of Liaoning & 21.4 & 21.8 & 0.108 & 25.6 & 63.5 & {$[26]$} \\
\hline Background values of China & 23.5 & 20.70 & 0.08 & 24.90 & 68.0 & {$[46]$} \\
\hline Background values of the world & 35 & 30 & 0.35 & 50 & 90 & {$[37]$} \\
\hline
\end{tabular}


Table 6. Statistical analysis of contamination index $(\mathrm{Pi})$ of each heavy metal in roadside soils of the Shenyang-Dalian Highway.

\begin{tabular}{|c|c|c|c|c|c|c|c|}
\hline & \multicolumn{3}{|c|}{ Pi } & \multicolumn{4}{c|}{ Number of soil sample } \\
\hline & minimum & maximum & average & No contamination & Low & Moderate & High \\
\hline $\mathrm{Pb}$ & 0.98 & 1.51 & 1.08 & 2 & 214 & 0 & 0 \\
\hline $\mathrm{Cu}$ & 0.40 & 2.65 & 0.98 & 106 & 105 & 5 & 0 \\
\hline $\mathrm{Cd}$ & 0.05 & 2.04 & 0.99 & 70 & 145 & 1 & 0 \\
\hline $\mathrm{Ni}$ & 0.61 & 2.02 & 1.27 & 45 & 170 & 1 & 0 \\
\hline $\mathrm{Zn}$ & 0.21 & 1.89 & 0.93 & 107 & 109 & 0 & 0 \\
\hline
\end{tabular}

soils were relatively clean. The mean $\mathrm{Pb}$ concentrations in all five cities were higher in 2013 and 2007 than in 1999 , illustrating that the total volume of heavy metal emissions increased over time. With the exception of $\mathrm{Cd}$, all heavy metal concentrations were significantly higher in 2013 than in 2007. After the 2004 expansion of the Shenyang-Dalian highway to an eight-lane, $120 \mathrm{~km} /$ hour highway, total vehicle capacity increased to 130-150 million. The mean traffic volumes in 1999, 2007, and 2013 were $820,1,250$, and 1,666 vehicles per hour, respectively [33]. Traffic density can be characterized as follows [35]: low traffic - less than 250 vehicles per hour, medium traffic - 250-1,500 vehicles per hour, and high traffic - more than 1,500 vehicles per hour. According to this classification, the traffic in Shenyang-Dalian Highway in 2007 was medium, and in 2013 heavy. The trends in total heavy metal concentrations in roadside soils are similar those of the highway traffic volume. This finding is compatible with previous studies showing that $\mathrm{Pb}, \mathrm{Cu}$, and $\mathrm{Zn}$ concentrations were closely linked to transportation activities [17, 25, 36].

We compared the average concentrations of heavy metals in this study with those in roadside soils from other cities around the world. Some soil background values from Liaoning, China, and the world were also listed in Table 5. The $\mathrm{Pb}$ concentrations in all areas were higher than the global background values, suggesting that $\mathrm{Pb}$ emissions from vehicle exhaust and their deposition in the vicinity of roads and highways has occurred globally. For example, $\mathrm{Pb}$ concentrations in roadside soil from Iran and Greece were almost 20 times the global reference value. $\mathrm{Zn}$ concentrations in Turkey, Saudi Arabia, Italy, Greece, Uganda, Iran, and Beijing, and $\mathrm{Cu}$ concentrations in Turkey, Italy, Greece, Nigeria, and Palestine were also higher than the global reference value. These findings illustrate the extent of the impact that traffic activities have on roadside soil pollution. Compared with Beijing, roadside soils in Liaoning contain higher levels of $\mathrm{Pb}$ and $\mathrm{Ni}$, and lower levels of $\mathrm{Cu}, \mathrm{Cd}$, and $\mathrm{Zn}$. As shown in Table 4, the mean concentrations of $\mathrm{Pb}, \mathrm{Cu}, \mathrm{Cd}, \mathrm{Ni}$, and $\mathrm{Zn}$ in roadside soils in this study are moderate compared to those in other cities around the world. It should be noted that several important factors might affect heavy metal concentrations, including traffic volume, number of local residents, fuel quality, distance of the sample from the road, and land use type [28].

\section{Assessment of Heavy Metal Contamination in Roadside Soils}

The statistical results of the Pi value for each heavy metal are represented in Table 6. The average Pi values for $\mathrm{Cu}, \mathrm{Cd}$, and $\mathrm{Zn}$ were less than 1, revealing no clear contamination of $\mathrm{Cu}, \mathrm{Cd}$, and $\mathrm{Zn}$. The mean $\mathrm{Pi}$ values for $\mathrm{Pb}$ and $\mathrm{Ni}$ were 1.08 and 1.27 , respectively, indicating low pollution. The $\mathrm{Pi}$ values varied widely between metals. The $\mathrm{Pi}$ values for $\mathrm{Pb}, \mathrm{Cu}, \mathrm{Cd}, \mathrm{Ni}$, and $\mathrm{Zn}$ in topsoil ranged $0.98-1.51,0.40-2.65,0.05-2.04,0.61-2.02$, and 0.21-1.89, respectively, indicating that the roadside soils along the Shenyang-Dalian Highway were unpolluted to moderately polluted. The proportions of heavy metals with low and intermediate $\mathrm{Pi}$ values for $\mathrm{Pb}, \mathrm{Cu}, \mathrm{Cd}, \mathrm{Ni}$, and $\mathrm{Zn}$ were $99.07 \%, 50.92 \%, 67.59 \%, 79.17 \%$, and $50.46 \%$, respectively. No samples had high levels of contamination, which indicated that there was no serious pollution in those areas and that most of the roadside soils had low or moderate levels of contamination.

As shown in Fig. 3, average pollution $\mathrm{Pi}$ in the roadside soils varied between five cities. The mean Pi values for $\mathrm{Pb}$ were highest in Shenyang and Dalian, which are the cities located at the origin and terminus, respectively, of the Shenyang-Dalian Highway and have heavier traffic relative to other cities. The Pi value for $\mathrm{Cd}$ in Anshan was higher than other cities, likely because the samples were collected from corn and rice fields subject to fertilization. The Pi values for $\mathrm{Ni}$ were relatively high in Anshan, Yingkou, and Dalian; Ni concentrations are closely

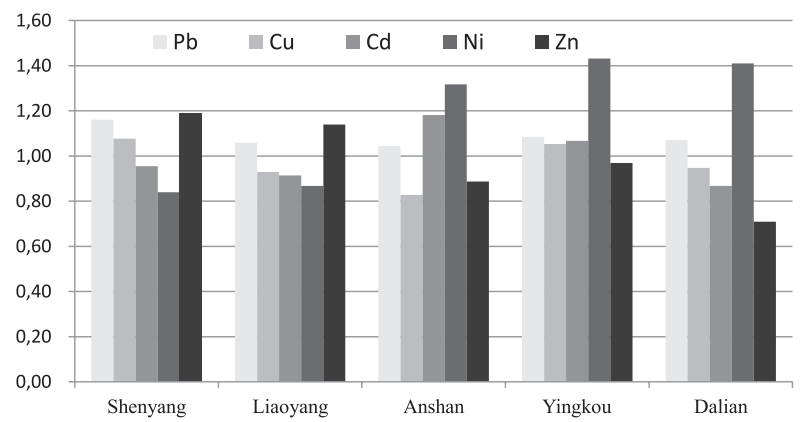

Fig. 3. The average pollution index (Pi) of heavy metals in roadside soils from the five cities along the Shenyang-Dalian Highway. 
Table 7. Nemerow pollution index (PI) of metals in surface soils.

\begin{tabular}{|c|c|c|c|c|c|c|c|}
\hline \multicolumn{3}{|c|}{ PI } & \multicolumn{5}{|c|}{ Number of samples } \\
\hline \multirow{2}{*}{ Min } & \multirow{2}{*}{ Max } & \multirow{2}{*}{ Mean } & No-pollution & Possible pollution & Low level & Middle level & High level \\
\cline { 4 - 9 } & & $(\mathrm{PI} \leq 0.7)$ & $(0.7<\mathrm{PI} \leq 1)$ & $(1<\mathrm{PI} \leq 2)$ & $(2<\mathrm{PI} \leq 3)$ & $(\mathrm{PI}>3)$ \\
\hline 0.90 & 2.31 & 1.23 & 0 & 11 & 201 & 4 & 0 \\
\hline
\end{tabular}

related to soil parent material, which may cause the high background value. The heavy metal contamination in all five cities is relatively low, and the primary source of all metals appears to be transportation activities.

The PIs of all samples ranged from 0.90-2.31, with a mean value of 1.23 (Table 7). No samples had $\mathrm{PI} \leq 0.7$, and 11 samples fell within the possibly polluted range $(0.7<\mathrm{PI} \leq 1)$, while 201 samples $(93.06 \%$ of samples) had a PI value between 1 and 2 ; four samples (1.9\% of samples) had a PI value between 2 and 3; and no samples had PI $>3$. Generally, these results indicate that topsoil along the Shenyang-Dalian Highway contain low levels of heavy metal pollution.

\section{Conclusions}

We analyzed concentrations of heavy metals in roadside soils along the Shenyang-Dalian Highway. Average concentrations of $\mathrm{Pb}, \mathrm{Cu}, \mathrm{Cd}, \mathrm{Ni}$, and $\mathrm{Zn}$ were 43.5, 26.9, $0.062,65.0$, and $73.5 \mathrm{mg} / \mathrm{kg}$, respectively. These results demonstrate that the average concentrations of heavy metals in these soils are higher than the background levels. Pearson's correlation analysis showed a significant positive correlation between $\mathrm{Pb}, \mathrm{Cu}$, and $\mathrm{Zn}$ concentrations, indicating a common source. We observed that the spatial distribution patterns varied according to land use types. There was a clear peak in heavy metal concentrations $25 \mathrm{~m}$ from the road shoulder, and non-normal distribution in the farmland soil. In areas containing orchard and forested land not in the vicinity of industrial activity, the heavy metal concentrations decreased with distance from the road and conformed to the exponential model in the forest and orchard soils. The distribution patterns were more obvious in areas with tall trees in the vicinity of the road, which appears to be the result of the entrapment capacity and interception ability of the trees compared with shorter crops such as corn. In the vicinity of industrial activity, there were no clear patterns in metal concentrations, which indicated that the impact of industrial activities outweighs the impact of transportation activities. Generally, sites on the eastern side had higher heavy metal concentrations than those on the western side because the heavy metals dispersed and accumulated in the downwind direction (east). We compared concentrations of the metals, except for $\mathrm{Cd}$, with those measured in a 2008 study [33]; the comparison demonstrated that heavy metal concentrations increased over time in the roadside soil. A comparison of this study with similar studies showed that concentrations of these metals in roadside soils along the Shenyang-
Dalian Highway are low to intermediate compared with those in roadside soils from other cities around the world.

The Pi values for heavy metals demonstrated that most roadside soils contained low levels of $\mathrm{Pb}, \mathrm{Cu}, \mathrm{Cd}, \mathrm{Ni}$, and $\mathrm{Zn}$ pollution, with some areas having moderate levels of $\mathrm{Cu}, \mathrm{Cd}$, and Ni pollution. Of the samples, $99.07 \%$ had some level of $\mathrm{Pb}$ pollution, indicating that $\mathrm{Pb}$ pollution due to traffic emissions is extensive. The degree of pollution in roadside soils varied slightly between the five cities. These results demonstrate that, overall, topsoil along the Shenyang-Dalian Highway has a low level of pollution as a result of vehicle emissions, and that attention should be given to $\mathrm{Pb}$ contamination in soils along the ShenyangDalian Highway.

\section{Acknowledgements}

Our study was supported by the Special Fund for Environmental Protection Research in the Public Interest (Nos. 20150940 and 201209029-1).

\section{References}

1. YIN R., WANG D., DENG H., SHI R., CHEN Z. Heavy Metal Contamination and Assessment of Roadside and Foliar Dust along the Outer-Ring Highway of Shanghai, China. J. Environ. Qual. 42, 1724, 2013.

2. CHEN X., XIA X., ZHAO Y., ZHANG P. Heavy metal concentrations in roadside soils and correlation with urban traffic in Beijing, China. J. Hazard. Mater. 181, 640, 2010.

3. BURNETT R. T., EZZATI M., OLIVES C., LIM S. S., MEHTA S., SHIN H. H., SINGH G., HUBBELL B., BRAUER M. An integrated risk function for estimating the global burden of disease attributable to ambient fine particulate matter exposure. Environ. Health Perspect. 122, 397, 2014.

4. POREBSKI G., WOŹNIAK M., CZARNOBILSKA E. Residential proximity to major roadways is associated with increased prevalence of allergic respiratory symptoms in children. Ann. Agric. Environ. Med. 21, 760, 2014.

5. AMARAN N. A., ABIDIN E. Z., RASDI I. Respiratory health symptoms and lung function among road-side hawkers in Serdang and its association with traffic-related exposures. Iran. J. Public. Health. 45, 77, 2016.

6. JANSSEN N.A.H., HOEK G., SIMIC-LAWSON M., FISCHER P., BREE L.V., BRINK H.T., KEUKEN M., W. ATKINSON R., ANDERSON H.R., BRUNEKREEF B., R. CASSEE F. Black Carbon as an Additional Indicator of the Adverse Health Effects of Airborne Particles Compared with $\mathrm{PM}_{10}$ and $\mathrm{PM}_{2.5}$. Environ. Health Perspect. 119, 1691, 2011. 
7. YANOSKY J.D., TONNE C.C., BEEVERS S.D., WILKINSON P., KELLY F.J. Modeling exposures to the oxidative potential of $\mathrm{PM}_{10}$. Environ. Sci. Technol. 46, 7612, 2012.

8. HAN N.M.I.M., LATIF M.T., OTHMAN M., DOMINICK D., MOHAMAD N., JUAHIR H., TAHIR N.M. Composition of selected heavy metals in road dust from Kuala Lumpur city centre. Environ. Earth. Sci. 72, 849, 2014.

9. GUNAWARDENA J., ZIYATH A. M., EGODAWATTA P., AYOKO G.A., GOONETILLEKE A. Sources and transport pathways of common heavy metals to urban road surfaces. Ecol. Eng. 77, 98, 2015.

10. HUANG H.B., CHEN G.W., WANG C.J., LIN Y.Y., LIOU S H., LAI C.H., WANG S.L. Exposure to heavy metals and polycyclic aromatic hydrocarbons and DNA damage in taiwanese traffic conductors. Cancer. Epidem. Biomar. 22, $102,2013$.

11. CHEN X., LU X., LI L.Y., YANG G. Spatial distribution and contamination assessment of heavy metals in urban topsoil from inside the Xi' an second ringroad, NW China. Environ. Earth. Sci. 68, 1979, 2013

12. CHEN T.B., ZHENG Y.M., LEI M., HUANG Z.C., WU H.T., CHEN H., FAN K.K., YU K., WU X., TIAN Q.Z. Assessment of heavy metal pollution in surface soils of urban parks in Beijing, China. Chemosphere. 60, 542, 2005.

13. HAMAMCI C., GUMGUM B., AKBA O., ERDOGAN S. Lead in urban street dust in Diyarbakir, Turkey. Fresenius Environ. Bull. 6, 430, 1997.

14. MCBRIDE M.B., SHAYLER H.A., SPLIETHOFF H.M., MITCHELL R.G., MARQUEZ-BRAVO L.G., FERENZ G.S., RUSSELL-ANELLI J.M., CASEY L., BACHMAN S. Concentrations of lead, cadmium and barium in urban garden-grown vegetables: The impact of soil variables. Environ. Pollut. 194, 254, 2014.

15. MACKINNON G., MACKENZIE A.B., COOK G.T., PULFORD I.D., DUNCAN H.J., SCOTT E.M. Spatial and temporal variations in $\mathrm{Pb}$ concentrations and isotopic composition in road dust, farmland soil and vegetation in proximity to roads since cessation of use of leaded petrol in the UK. Sci. Total. Environ. 409, 5010, 2011.

16. BOURLIVA A., CHRISTOPHORIDIS C., PAPADOPOULOU L., GIOURI K., PAPADOPOULOS A., MITSIKA E., FYTIANOS K. Characterization, heavy metal content and health risk assessment of urban road dusts from the historic center of the city of Thessaloniki, Greece. Environ. Geochem Health. 2016.

17. WEI B., YANG L. A review of heavy metal contaminations in urban soils, urban road dusts and agricultural soils from China. Microchem J. 94, 99, 2010.

18. PYTEL Z. Evaluation of potential applications of recycled moulding and core sands to production of ceramic building materials. Ceram. Int. 40, 4351, 2014.

19. BABU A.G., JAEHONG S., BANG K.S., SHEA P.J., BYUNGTAEK O. Trichoderma virens PDR-28: a heavy metal-tolerant and plant growth-promoting fungus for remediation and bioenergy crop production on mine tailing soil. J. Environ. Manage. 132, 129, 2014.

20. PATEL A., PATRA D.D. Influence of heavy metal rich tannery sludge on soil enzymes vis-a-vis growth of Tagetes minuta, an essential oil bearing crop. Chemosphere. 112, 323, 2014.

21. CLEMENS S., JIAN F.M. Toxic Heavy Metal and Metalloid Accumulation in Crop Plants and Foods. Plant Biology. 67, 489, 2016.

22. ROTHENBERG S.E., WINDHAM-MYERS L., CRESWELL J.E. Rice methylmercury exposure and mitigation: A comprehensive review. Environ. Res. 133, 407, 2014.

23. KRISTENSSON A., JOHANSSON C., WESTERHOLM R., SWIETLICKI E., GIDHAGEN L., WIDEQVIST U., VESELY V. Real-world traffic emission factors of gases and particles measured in a road tunnel in Stockholm, Sweden. Atmos. Environ. 38, 657, 2015.

24. HAN X., LU X., ZHANG Q., WUYUNTANA, HAI Q., PAN H. Grain-size distribution and contamination characteristics of heavy metal in street dust of Baotou, China. Environ. Earth Sci. 75, 468. 2016.

25. FENG J., ZHAO J., BIAN X., WANG Z. Spatial distribution and controlling factors of heavy metals contents in paddy soil and crop grains of rice-wheat cropping system along highway in East China. Environ. Geochem. Health. 34, 605, 2012.

26. LAWRENCE S., SOKHI R., RAVINDRA K., MAO H., PRAIN H.D., BULL I.D. Source apportionment of traffic emissions of particulate matter using tunnel measurements. Atmos. Environ. 77, 548, 2013.

27. PUTH M.T., NEUH USER M., RUXTON G.D. Effective use of Pearson's product-moment correlation coefficient. Anim. Behav. 93, 183, 2014.

28. JC N. Assessment of heavy metal contamination of agricultural soils and cassava leaves along umuahia -ikotekpene highway, abia state. 6, 975, 2015.

29. LI Y.Z., MA J.H., MO S.J. Heavy metals pollution in roadside soils and source identification, Guangzhou Agri Sci. 40, 174, 2013

30. YAN X.D., DAN G., FAN Z., CHEN Z., WANG X., MAN $Z$. Relationships between heavy metal concentrations in roadside topsoil and distance to road edge based on field observations in the Qinghai-Tibet Plateau, China. Inter. J. Env. Res. Pub. Heal. 10, 762, 2013.

31. VON D.L.M., BULLOCK J.M., KOWARIK I., KNOPP T., WICHMANN M.C., WICHMANN M. Human-mediated dispersal of seeds by the airflow of vehicles. PloS One. 8 , e52733, 2013.

32. SANDERSON P., DELGADO-SABORIT J.M., HARRISON R.M. A review of chemical and physical characterisation of atmospheric metallic nanoparticles. Atmos. Environ. 94, 353, 2014.

33. HONG Z. Distribution characteristics of soil heavy metal pollution at both sides of the roads along ShenyangDalian expressway. J. Meteor. and Environ. 2, 6, 2008 [In Chinese].

34. ZHANG Z., CHANG Y. Lead pollution in soil beside Shenyang-Dalian Superhighway. Liaoning Urban and Rural Environmental Science \& Technology. 19, 51, 1999 [In Chinese].

35. FAKAYODE S.O., OLU-OWOLABI B.I. Heavy metal contamination of roadside topsoil in Osogbo, Nigeria: its relationship to traffic density and proximity to highways, Environ. Environ. Geol. 44, 150, 2003.

36. SAEEDI M., HOSSEINZADEH M., JAMSHIDI A., PAJOOHESHFAR S.P. Assessment of heavy metals contamination and leaching characteristics in highway side soils, Iran. Environ. Monit. Assess. 151, 231, 2009.

37. CHINA NATIONAL ENVIRONMENTAL MONITORING CENTER. The Backgrounds of Soil Environment in China, China Environmental Science Press, Beijing. Beijing: China Environmental Science Press. 1990.

38. DAO L., MORRISON L., ZHANG C. Spatial variation of urban soil geochemistry in a roadside sports ground in Galway, Ireland. Sci. Total. Environ. 408, 1076, 2010.

39. GUNEY M., ONAY T.T., COPTY N.K. Impact of overland 
traffic on heavy metal levels in highway dust and soils of Istanbul, Turkey. Environ. Monit. Assess. 164, 101, 2010.

40. KADI M.W. Soil Pollution Hazardous to Environment: A case study on the chemical composition and correlation to automobile traffic of the roadside soil of Jeddah city, Saudi Arabia. J. Hazard. Mater. 168, 1280, 2009.

41. IMPERATO M., ADAMO P., NAIMO D., ARIENZO M., STANZIONE D., VIOLANTE P. Spatial distribution of heavy metals in urban soils of Naples city (Italy). Environ. Pollut. 124, 247, 2003.

42. CHRISTOFORIDIS A., STAMATIS N. Heavy metal contamination in street dust and roadside soil along the major national road in Kavala's region, Greece. Geoderma. 151, 257, 2009.

43. OLAJIRE A.A., AYODELE E.T. Contamination of roadside soil and grass with heavy meals. Environ. Int. 23, 91, 1997.
44. NABULO G., ORYEM-ORIGA H., DIAMOND M. Assessment of lead, cadmium, and Zinc contamination of roadside soils, surface films, and vegetables in Kampala ity, Uganda. Environ. Res. 101, 42, 2006.

45. SWAILEH K.M., HUSSEIN R.M., ABU-ELHAJ S. Assessment of heavy metal contamination in roadside surface soil and vegetation from the West Bank. Arch. Environ. Health. 47, 23, 2004.

46. GRANTAN I.L., TAGLION I.S., CRESCENTE M.F. The accumulation of lead in agricultural soil and vegetation along a highway. Chemosphere. 24, 941, 1992.

47. NTAKIRUTIMANA T., GANG D., GUO J.S., XU G., LEI H. Pollution and Potential Ecological Risk Assessment of Heavy Metals in a Lake. Pol. J. Environ. Stud. 22, 1129, 2013.

48. MINISTRY OF ENVIRONMENTAL PROTECTION OF CHINA. Soil Environmental Quality Standards in China(GB15618), Beijing, 1995. 
